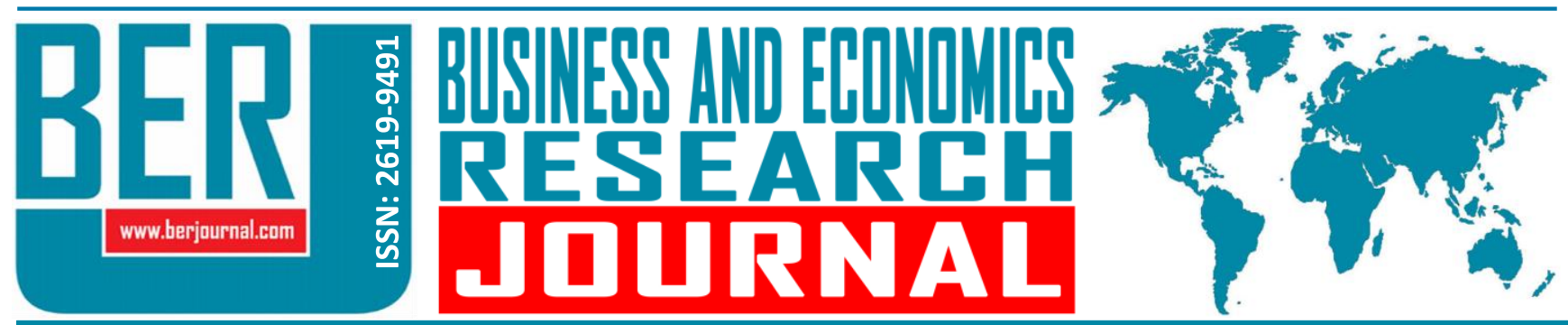

Business and Economics Research Journal Vol. 12, No.2, $2021 \quad$ pp. 339-358 doi: 10.20409/berj.2021.325

\title{
Long-Run Price and Operating Performance of Initial Public Offerings in Borsa Istanbul
}

\section{S. Burcu Avci ${ }^{\mathrm{a}}$}

Abstract: This study investigates long-run price and operating performance of initial public offerings (IPOs) in Borsa Istanbul. The sample period of the analysis is between 2010 and 2019. Various findings are obtained by employing several analytical methods. First, long-run price performance of IPOs is negative. Evidence shows that large issues are likely to have relatively higher long-run returns than smaller issues. On the other hand, if an issue is made in a hot-issue period, it is likely to have relatively more severe underperformance in the long-term. Second, long-run operating performance is also negative. Third, the relationship between long-run abnormal price performance and operating performance is significantly negative when asset efficiency or return on equity are used as a measure of operating performance. The higher the issuing company's asset efficiency or equity efficiency is, more likely it is to have a severe abnormal price underperformance in their post-IPO years. This finding is weaker for return on equity, the explanatory power of return on equity may be seized by capital increase ratio in some model specifications. These results together support "windows of opportunity" theory of price and operating performance of IPOs.
Keywords: Price

Performance, Buy-and-Hold Abnormal Returns, Wealth Relatives, Operational Performance, Windows of Opportunity

JEL: G11, G14, G32

$\begin{array}{ll}\text { Received } & : 28 \text { December } 2020 \\ \text { Revised } & : 25 \text { March } 2021 \\ \text { Accepted } & : \text { 16 April } 2021 \\ \text { Type } & : \text { Research }\end{array}$

\section{Introduction}

IPO markets have long been of importance because of initial public offering (IPO) mispricing. Initial underpricing and hot markets anomalies are accompanied with long-run overpricing. The initial underpricing reverses at some point within a year in the aftermarket of the IPO and the overpricing trend continues for a long time. From one point of view, this is the market correction of the price. However, it has important financial consequences on the issuing company, the market, and the investors (Ritter, 1991). For example, investors may form portfolios based on these price anomalies.

"Windows of opportunity" theory developed by Ritter (1991) argues that issuing companies have strong operational and financial performance, as a result, investors are overoptimistic about their prospects in the long-term. After the firm becomes public, it cannot last its superior operating performance and end up with having long-run negative abnormal returns. This theory requires drops in the operating and price performance of the issuing company in the long-run. The theory causes the long-term IPO studies to theorize and analyze price performance and operating performance separately and infer a positive correlation between them.

a PhD., Visiting Researcher at Sabancı University, School of Business, Istanbul, Turkiye, avcis@sabanciuniv.edu (ORCID ID: 00000001-8056-8509) 
Long-run price performance and operational performance of IPOs in Borsa Istanbul (BIST) have been examined in the literature. Earlier research finds that both price performance (Ünlü, 2006; Bildik \& Yılmaz, 2008; Kırkkulak, 2010; Turan Kurtaran, 2013; Tütüncü \& Uzunel, 2020) and operating performance (Kurtaran \& Er, 2008; Arık \& Mutlu, 2015; Kurtaran Çelik, 2016; Tütüncü \& Uzunel, 2020) fall in the post-IPO period. The aim of this study is, first, to look at long-run price and operating performance of IPOs separately and to see if they drop simultaneously as existing literature suggests. Second, it looks for a relationship between price performance and operating performance. This study looks deeper into the findings in these studies in an attempt to find the connection between these two phenomena.

We expect to see long run overpricing and operating underperformance in the IPO aftermarket. Moreover, we also hypothesize that long-run overpricing is related to operational or company-specific features of the issuing company. In other words, we try to explain the long-run overpricing with short-run and long-run factors. This paper contributes to literature from several ways. First, it establishes long-run price and operating underperformance of IPOs in Turkish market after 2010 and provides evidence supporting "windows of opportunity" theory. Second, it puts forward a relationship between operational performance and long-run price performance of issuing companies. It establishes that issuing companies with higher asset efficiency and equity efficiency are more likely to underperform in the long-term. To the best of our knowledge, this relationship has never been determined before.

The sample of this study is 130 IPOs at the BIST between 2010 and 2019. Long-run price performances of IPO companies are computed for one to five years using buy-and-hold return methodology. Wealth relatives and cumulative abnormal return methodologies are also used to provide robustness to our results. Long-run operating performance is measured by testing the difference between the values of two operating performance ratios in consecutive years of certain financial ratios. Long-run performance ratios are computed for three years after the IPO.

The two separate findings of this paper are consistent with windows of opportunity theory. The theory states that companies prefer issuing stocks when market conditions are advantageous. They would issue if managers have optimistic expectations about company's forecasts ( Ritter, 1991; Loughran \& Ritter, 1995, 1997; Cai \& Wei, 1997). One set of tests in this article determines long-run abnormal returns and tries to find factors affecting long-run returns. Consistent with the existing literature, we find negative and significant long-run abnormal returns of IPOs. Another set of tests in this article examines the long-run operating performance of issuing firms. In line with existing studies, our results show that operating performance of issuing companies is negative. These results are in line with windows of opportunity theory: Issued during the overvaluation period, a firm cannot continue its recent superior operational performance and ends up with long-run underperformance (Ritter, 1991; Loughran \& Ritter, 1995, 1997; Cai \& Wei, 1997; Pástor \& Veronesi, 2005; Pástor, Taylor, \& Veronesi, 2009).

To determine the connection between long-run price performance and long-run operational performance, we run bivariate and multivariate regressions. Results show that long-run abnormal returns are negatively related to asset efficiency measure (asset turnover ratio) and equity efficiency measure (return on equity). Tests show that the sign and the power of the relation is stable regardless of the time period when performance indicators are measured. Moreover, proceeds, hot period dummy, and capital ratio are the three significant factors in association with long-run abnormal profits.

This remainder of the study is organized as follows: Section two reviews the theoretical and empirical literature on long-run price performance and long-run operational performance of IPOs. Section three introduces data and methodology. Section four presents empirical results. Section five reviews robustness tests and Section six concludes. 


\section{Literature Review}

\subsection{Long-Run Price Performance of IPOs}

Long-run price performance of IPOs have been measured by using three approaches. The first and most widely used method computes equally weighted buy-and-hold returns (BHARs) or cumulative abnormal returns (CARs) for longer periods. Studies using long-run BHARs find a long-run underperformance of stock prices (Stoll \& Curley, 1970; Ibbotson, 1975; Ritter, 1991; Loughran, 1993; Loughran, Ritter, \& Rydqvist, 1994; Loughran \& Ritter, 1995; Spiess \& Affleck-Graves, 1995; Dark, \& Singh, 1998; Brav, Geczy, \& Gompers, 2000; Houge, Loughran, Suchanek, \& Yan, 2001; Ritter \& Welch, 2002; Carter, Dark, Floros, \& Sapp, 2011; Carter, Dong, Michel, \& Pandes, 2011). On the other hand, studies using CARs find a long-run price underperformance (Brav et al., 2000; Schultz, 2003; Gao, Mao, \& Zhong, 2006).

A caveat about CARs and BHARs is necessary here. Because each day has an equal weight in CARs, the abnormal return will have an upward bias: Lower priced firms' daily return will be substantially higher than the higher priced firms' daily return, and number of firms underpriced is generally higher than number of firms overpriced. This bias is not related to market overreaction, it is rather a measurement error (Conrad \& Kaul, 1993; Barber \& Lyon, 1997). Thus, BHARs is a more reliable methodology to measure long-run price performance. In line with this explanation, we have discovered that some studies analyzing long-run price performance of Turkish IPOs using CARs find positive long-run abnormal returns (Tükel, 2010; Turan Kurtaran, 2013) while studies using BHARs find negative long-run abnormal returns (Bildik \& Yılmaz, 2008; Kırkkulak, 2010; Turan Kurtaran, 2013).

The second method to measure long-run price performance matches IPOs to public firms in terms of industry, size, and market-to-book ratio. Long-run price performances of issuing firms and their industry peers are compared. A higher price performance is achieved if issuing firms' long-run price performance is significantly higher than price performance of peers. Results of these tests are similar to the results of the first method: IPO firms underperform matching firms in the long run (Ritter, 1991; Loughran \& Ritter, 1995; Affleck-Graves, Hegde, \& Miller, 1996; Brav et al., 2000; Eckbo \& Norli, 2005; Carter et al., 2011; Dong et al., 2011). The second method tests provide interesting findings; however, they are tests of similar public companies rather than tests of IPOs (Ritter \& Welch, 2002).

Using the first two methods, several theoretical explanations were developed to explain the long-run price underperformance phenomenon. The first and a prominent theory is "windows of opportunity" hypothesis developed by Ritter (1991). This hypothesis argues that issuing companies have strong operational and financial performance, as a result, investors are overoptimistic about their prospects in the long-term. As operating and financial performance goes down in time in the post-IPO period, the value of the company falls along with long-run returns. High growth firms are the best example for such companies (Loughran, 1993; Xiao \& Yung, 2015).

Given that growth prospects or future operating performance of hot versus cold IPO market companies are not different from each other (Helwege \& Liang, 2004), the market timing theory explains the hot issue periods as clusters of less successful IPOs following a (or a few) pioneer successful IPO(s). Supporting this thesis, (Loughran \& Ritter, 1995) claims that market-to-book values can explain only a small fraction of aftermarket underperformance. When the long-run return is measured as an equal weighted average of all these successful and not successful IPOs, the average return is negative (Schultz, 2003). This theory best explains the fact that underperformance is severe after hot issue periods, which is documented in Ritter (1991). Moreover, there is empirical evidence that if there is higher degree of overvaluation in an IPO on the offer date, it is underpriced more in the first day returns and tend to underperform more in the long-term (Purnanandam \& Swaminathan, 2004; Turan Kurtaran, 2013).

The third approach measures long-run price performance via calendar time regressions with FamaFrench factors. The idea of using rolling window time series regressions helps compare the abnormal returns with temporal financial factors. These studies usually find no underperformance in the returns of IPOs and explain the long-run underperformance found by the first two methods as a result of risk exposures of IPO 
firms rather than the fact that they have gone public (Brav et al., 2000; Gompers \& Lerner, 2000; Ritter \& Welch, 2002; Eckbo \& Norli, 2005; Lyandres, Le, \& Zhang, 2008). This theory is silent about the high number of IPOs and severe post-IPO underperformance of hot issue periods (Schultz, 2003).

Studies regarding long-run price performance of IPOs for Borsa Istanbul (BIST) find ambiguous results: studies using a long analysis period and large sample find negative BHARs in the long-run for up to three or five years (Ünlü, 2006; Bildik \& Yılmaz, 2008; Kırkkulak, 2010; Turan Kurtaran, 2013; Tütüncü \& Uzunel, 2020). However, insignificant (Ayden \& Karan, 2000) and positive (Kaya, 2017) long-run BHARs are also present in the literature. As stated before, studies employing CAR methodology to compute long-run abnormal returns find positive and significant abnormal returns in the long-term (Tükel, 2010; Turan Kurtaran, 2013).

\subsection{Long-Run Operating Performance of IPOs}

The literature documents long-run price underperformance of IPOs is present simultaneously with long-run operating underperformance (Jain \& Kini, 1994). As a result, the correlation between long-run price and operating performances of IPOs is positive. Studies find positive operating performance just after the IPO, consistent with "windows of opportunity" theory, and then significant drops in operational performance of issuing companies in long-term periods (usually from one to five years). The operating performance measures used in these studies are different combinations of return on assets, return on equity, operating cash flows to total assets, sales, asset turnover, capital expenditures, non-operating profit to total profit, and net income (Jain \& Kini, 1994; Cai \& Wei, 1997; Chui, Lau, \& Ip, 2001).

A wide-spread method to measure long-run operating underperformance is to compare IPO companies' financial ratios with industry-matched peers' financial ratios. If issuing companies' financial ratios drop more than those of the peers, than we can claim performance drops in IPO companies (Jain \& Kini, 1994; Cai \& Wei, 1997; Balatbat, Taylor, \& Walter, 2004; Tütüncü and uzunel, 2020). A second method to analyze performance changes is to compute the difference between financial ratios of consecutive years and to test if the difference is significantly different from zero (Chui et al., 2001; Wang, 2005; Chi \& Padgett, 2006; Chipeta \& Jardine, 2014; Arık \& Mutlu, 2015; Kurtaran Çelik, 2016).

Theoretically, "windows of opportunity" hypothesis does a good job to explain the variability in the long-run operating performance. In this context, we can claim that managers would issue if they have optimistic expectations about company's forecasts to benefit from temporary conditions in the market (Ritter, 1991; Loughran \& Ritter, 1995, 1997; Cai \& Wei, 1997; Pástor \& Veronesi, 2005; Pástor et al., 2009). After the firm becomes public, it cannot last its superior operating performance and end up with having longrun negative abnormal returns. Korajczyk, Lucas, and McDonald (1991) shows that firms go public when the market knows them the best when they release post earnings announcements and other financial tables. In later periods, they do not release that much information, hence stock prices fall.

Studies analyzing long-run operating performance of IPOs in Borsa Istanbul (BIST) find long-run operational underperformance in financial performance for about three post-IPO years (Kurtaran \& Er, 2008; Arık \& Mutlu, 2015; Kurtaran Çelik, 2016; Tütüncü \& Uzunel, 2020). Kurtaran \& Er (2008) find that managerial ownership and post-issue performance have a positive relation. Arık \& Mutlu (2015) find that number of intermediaries, intermediation type, and firm specific corporate governance practices play a significant role on the long-run operating performance.

\section{Data and Methodology}

Sample period of this study is 10 years from January 2010 to December 2019. IPO information is collected from BIST datastore ${ }^{1}$ and Capital Markets Board of Turkey website ${ }^{2}$ and combined. The data set has 130 IPOs to analyze for the entire sample period. This dataset provides a list of IPOs, dates, offer prices, underwriters and related information. Daily share prices, number of shares outstanding, financial ratios, and daily prices of BIST100 index are obtained from EquityRT. 
Variables used in this study are: Number of IPOs $(N)$ is the number of IPOs realized a year. Abnormal return $(A R)$ is the abnormal return calculated as the difference of daily company return and daily stock market index return. $A R$ is the initial abnormal return of the first trading day. Initial return is the return from offer price to the first public trading day closing price (Equation 1). $A R$ is computed as subtracting market return (BIST100 index return) from the initial return (Equation 2). Real proceeds (Proceeds) are lira (Turkish Lira) amount collected by the issuing company on the offer date. Real aggregate gross proceeds in 2019 numbers are the annual sum of real proceeds from each IPO. Real money left on the table (Money_left) is computed as number of shares offered multiplied by the difference between the first trading day closing price and offer price. Money left on the table is the lira amount that directly goes to investors' pocket instead of issuing company. Real aggregate money left on the table in 2019 numbers is an annual sum of real money left on the table. The nominal values of proceeds and money_left are transformed to real values as of December 31, 2019 numbers by using the inflation calculator of the Central Bank of the Republic of Turkey (TCMB) ${ }^{3}$. MarCap is the market capitalization of the issuing company on the offer date. $D_{H}$ is a dummy variable that takes the value of 1 if the IPO is realized in a hot issue market and takes the value of 0 otherwise. $D_{O}$ is a dummy variable that takes the value of 1 if capital increase ratio is above its median value, 0 otherwise. Capital increase ratio is computed as the ratio of capital increased through the IPO divided by the total capital. BHARs are buy-and-hold abnormal returns (Equations 3 and 4), and WRs are wealth relatives (Equations 5 and 6), CARs are cumulative abnormal returns (Equation 7) computed using daily stock and index returns.

$$
R_{i, t}=\left[\frac{P_{i, t}-P_{i, t-1}}{P_{i, t-1}}\right] \times 100
$$

where $\mathrm{P}_{\mathrm{i}, \mathrm{t}}$ represents first trading day closing price and $\mathrm{P}_{\mathrm{i}, \mathrm{t}-1}$ represents the offer price of the IPO. Market adjusted returns are computed to measure abnormal returns for each stock.

$$
A R_{i, t}=R_{i, t}-R_{m, t}
$$

where $A R_{i, t}$ is the daily abnormal return of stock $i$ at day t. $R_{i, t}$ is the daily return of stock $i$ and $R_{m, t}$ is the daily stock market portfolio return at day t. BIST100 index is assumed to be the average return on the market portfolio.

After market returns are computed by equation (1), where $\mathrm{P}_{\mathrm{i}, \mathrm{t}}$ and $\mathrm{P}_{\mathrm{i}, \mathrm{t}}$ represent consecutive aftermarket returns. Event-time buy-and-hold abnormal returns (BHARs) are computed to account for post-IPO price performance. Equations ( 3 ) and (4) compute BHARs.

$$
\begin{aligned}
& B H A R_{i, t}=\prod_{t=1}^{n}\left(1+R_{i, t}\right)-\prod_{t=1}^{n}\left(1+R_{m, t}\right) \\
& B H A R=\sum_{i=1}^{n} B H A R_{i}
\end{aligned}
$$

An alternative measure, event time wealth relatives (WRs) are computed for the post-IPO price performance (Loughran \& Ritter, 1995) as follows:

$$
\begin{aligned}
& W R_{j, t}=\frac{\prod_{t=1}^{n}\left(1+R_{j, t}\right)}{\prod_{t=1}^{n}\left(1+R_{m, t}\right)} \\
& W R=\sum_{j=1}^{n} W R_{j}
\end{aligned}
$$


A second alternative measure, cumulative abnormal returns (CARs) are also presented as a measure of long-run price performance as follows:

$$
C A R_{i, t}=\sum_{i=1}^{n} A R_{i, t}
$$

BHARs, WRs, and CARs are computed on day-zero (initial abnormal returns), one-, three-, and sixmonth (mid-run), one-, two-, three-, and five-year (long-run) basis. T-tests are used to test the statistical significance of BHARs, WRs, and CARs. Moreover, median values are also used to test the statistical significance because the dataset is not normally distributed. Wilcoxon sign-rank test is employed to test the statistical significance of median values.

Hot issue periods are computed as follows: number of issuances each month are determined and grouped into five categories based on quartiles (Helwege \& Liang, 2004). Following this method, number of IPOs in each of 120 months in the sample period is determined. The highest quartile months are labelled as hot period. The lowest two quartiles are labelled as cold period because the number of IPOs is only a few in the lowest quartile; the third and fourth quartiles are named as neutral periods. Based on this classification hot, neutral, and cold periods in the dataset have 72, 30, and 28 observations, respectively.

Table 1. Times Series and Cross-Sectional Summary Statistics of IPOs

\begin{tabular}{|c|c|c|c|c|}
\hline \multicolumn{5}{|c|}{ Panel A: Time Series Statistics } \\
\hline Year & $N$ & Gross $A R$ & $\begin{array}{l}\text { Real Gross } \\
\text { Proceeds }\end{array}$ & $\begin{array}{l}\text { Real Gross } \\
\text { Money_Left }\end{array}$ \\
\hline 2010 & 20 & $5.10 \%$ & 374.00 & 63.60 \\
\hline 2011 & 27 & $5.97 \%$ & 116.00 & 26.80 \\
\hline 2012 & 26 & $4.07 \%$ & 50.60 & 0.67 \\
\hline 2013 & 18 & $6.47 \%$ & 153.00 & 11.00 \\
\hline 2014 & 13 & $2.90 \%$ & 97.80 & 3.06 \\
\hline 2015 & 6 & $4.34 \%$ & 33.60 & 3.93 \\
\hline 2016 & 2 & $-0.83 \%$ & 272.00 & -0.57 \\
\hline 2017 & 3 & $4.04 \%$ & 595.00 & 37.20 \\
\hline 2018 & 9 & $5.12 \%$ & 781.00 & 19.90 \\
\hline 2019 & 6 & $6.84 \%$ & 45.50 & 10.50 \\
\hline \multicolumn{5}{|c|}{ Panel B: Cross-Sectional Statistics } \\
\hline Observations & 130 & & 198.00 & 20.20 \\
\hline Average & 13.00 & $4.97 \%$ & 251.85 & 17.61 \\
\hline Minimum & 2.00 & $-0.83 \%$ & 33.60 & -0.57 \\
\hline Maximum & 27.00 & $6.84 \%$ & 781.00 & 63.60 \\
\hline Correlation with $N$ & 1.00 & 0.41 & -0.32 & 0.20 \\
\hline Correlation with $A R$ & 0.41 & 1.00 & -0.07 & 0.33 \\
\hline
\end{tabular}

This table presents summary statistics of $N$, gross $A R$, real gross proceeds, and real gross money_left. Panel $\mathrm{A}$ contains time series summary statistics, and Panel $B$ contains cross-sectional summary statistics. $N$ is IPO volume (number of IPOs), gross $A R$ is market adjusted annual abnormal returns, real gross proceeds are real aggregate gross proceeds with 2019 numbers. Real gross proceeds are real annual proceeds computed as number of issues sold multiplied by sales price at the offer market. Money_left is real aggregate money-left on the table with 2019 numbers. Money_left is computed as multiplying number of shares offered by the difference between first trading day close price and the offer price.

Table 1 displays a summary of annual IPO volume $(N)$, gross $A R$, real gross proceeds, and real gross money_left values. $N$ has maximum values between 2010 and 2012 with more than 20 issuances per year; then $N$ reduces to single digits in 2015 and following years. The maximum number of IPOs in a year was 27 in 2011. $A R$ is around 4\%-6\% with and exception of 2014 (2.90\%) and $2016(-0.83 \%)$. Proceeds fluctuate between $\$ 34$ million and $\$ 781$ million and has negative correlation with IPO volume $(-32 \%)$ and average 
annual initial returns (gross AR) (-7\%). Money_left has positive correlation with IPO volume (20\%) and average annual initial returns (33\%).

Figure 1 displays the annual median values of $A T, O M, P M$, and $R O E$ ratios around IPO year. Year 0 is the IPO year; values of ratios are presented for a total of five years (two years before and two years after the IPO). $A T$ is displayed separately in Panel $\mathrm{A}$ because its median values are remarkably higher than the median values of other performance indicators. Two different panels provide a better visualization to observe the variability in ratios. Panel A shows that $A T$ declines before and during the IPO year from its higher levels. It reaches a minimum one year after the IPO and increase again. This shows IPOs are realized when asset efficiency is already in a declining trend. ROE and OM reach their maximums one year before the IPO and declines afterwards to lower than pre-IPO levels. PM increases one year before the IPO and reaches its maximum on IPO year. However, it declines back to pre-IPO levels one year after the IPO and continues declining in the second year after the IPO. Overall, we observe a trend of decline in all performance measures after the IPO year.

Four operating ratios are used to measure the operating performance of IPO companies in annual basis: Asset turnover ratio $(A T)$, operating margin $(O M)$, profit margin $(P M)$, and return on equity $(R O E)$. $A T$ is computed as dividing net sales by total assets. $A T$ indicates efficiency of assets to generate revenue. $O M$ is computed as dividing EBIT (earnings before interest and taxes) by net sales. OM helps understand if a company is making profits mainly from its core operations or from other means such as non-operating investments. $P M$ is computed as dividing earnings (net income) by net sales. $P M$ shows how much of earnings are coming from sales. ROE is computed as dividing earnings by shareholders' equity. It measures the efficiency of shareholders' equity. Change in the operating performance is computed between years and the differenced series are tested by a non-parametric Wilcoxon sign rank test to be significantly different from previous years.

$$
W=\sum_{i=1}^{N}\left[\operatorname{sgn}\left(x_{2, i} x_{1, i}\right) . R_{i}\right]
$$

where sgn is the sign function; $\mathrm{X}_{1, \mathrm{i}}$ and $\mathrm{X}_{2, \mathrm{i}}$ are paired measurements of the same variable in two different years, and $R_{i}$ is the rank of the sample pairs. A Z-test is employed to measure the significance of the Wilcoxon sign rank test.

Pairwise correlation coefficients between variables are presented in Table 2. A majority of the variables have weak relationship while a few have remarkably high correlation coefficients. First, money_left and proceeds have a strong positive correlation at $54 \%$, which indicates that the money left on the table is greater for larger IPOs. Second, $A R$ has strong negative correlation coefficients with all the financial ratios: The better the financial indicators of the IPO company are, the less underpriced it is. Last, the correlation coefficient between $A T$ and $R O E(85 \%)$; and $O M$ and $P M(100 \%)$ are highly positive and strong. This high correlation is expected because of high similarity in these ratios. 


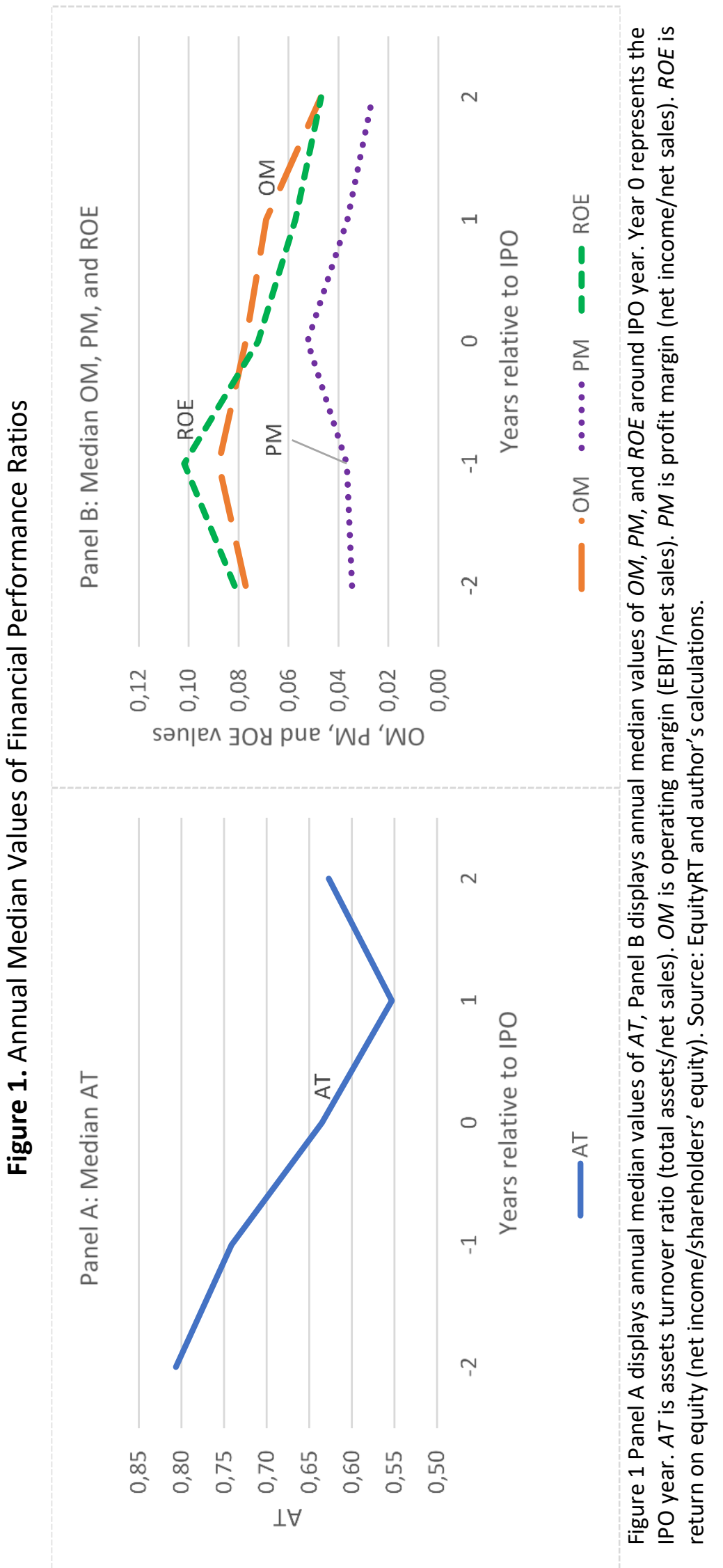




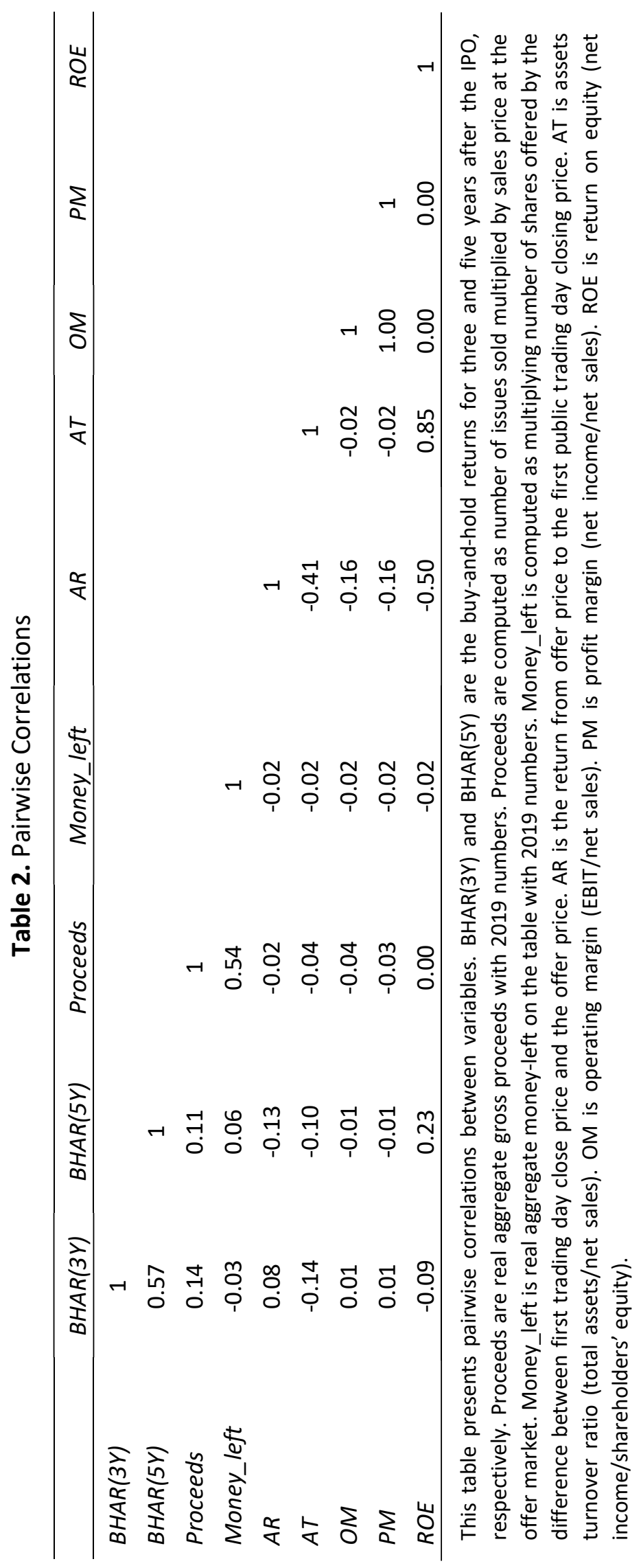




\section{Empirical Findings}

\subsection{Long-run IPO Prices}

Empirical analysis starts with determining long-term BHARs. Table 3 reports BHARs of equally weighted portfolio of IPOs and their summary for the entire sample. $B H A R(0)$ is the initial abnormal return; $B H A R(1 M)-B A H R(6 M)$ are middle-term (one- to six-month) BHARs; and BHAR(1Y)-BHAR(5Y) are long-term (one- to five-year) BHARs. BHAR(O) uses the full sample of 130 firms while mid-term and long-term BHAR measures lose the latest IPOs. For example, the $B H A R(5 Y)$ has only 93 IPOs, all of which took place before 2015.

Table 3. Summary of Market-Adjusted Buy-and-Hold Abnormal Returns (BHARs)

\begin{tabular}{lccccccc}
\hline Variables & $\mathrm{N}$ & Mean & Median & Min. & Max. & t-Stat & z-Stat. \\
\hline BHAR $(0)$ & 130 & $4.98 \% * * *$ & $2.07 \% * * *$ & $-17.20 \%$ & $31.47 \%$ & 6.23 & 4.88 \\
BHAR $(1 M)$ & 130 & $4.78 \% * *$ & $-0.88 \%$ & $-37.83 \%$ & $115.66 \%$ & 2.29 & 0.66 \\
BHAR $(3 M)$ & 129 & $10.20 \% * * *$ & $1.28 \%$ & $-49.50 \%$ & $271.13 \%$ & 2.71 & 1.40 \\
BHAR $(6 M)$ & 127 & $10.68 \% * *$ & $-2.93 \%$ & $-90.13 \%$ & $241.30 \%$ & 2.15 & 0.61 \\
BHAR $(1 Y)$ & 123 & $-0.53 \%$ & $-10.89 \% *$ & $-99.38 \%$ & $331.22 \%$ & -0.09 & -1.77 \\
BHAR $(2 Y)$ & 119 & $-6.75 \%$ & $-21.46 \% * * *$ & $-107.42 \%$ & $615.35 \%$ & -0.83 & -3.12 \\
BHAR $(3 Y)$ & 108 & $-16.28 \% *$ & $-43.38 \% * * *$ & $-148.58 \%$ & $295.21 \%$ & -1.89 & -3.34 \\
BHAR $(5 Y)$ & 93 & $-9.43 \%$ & $-57.68 \% * * *$ & $-133.43 \%$ & $712.75 \%$ & -0.68 & -3.41 \\
\hline BHAR $(0)$
\end{tabular}

$B H A R(0)$ is equal to initial abnormal return. $B H A R(1 M), B H A R(3 M)$, and $B H A R(6 M)$ are one-, three-, and six-month market adjusted buy-and-hold abnormal returns, respectively. $B H A R(1 Y), B H A R(2 Y), B H A R(3 Y)$, and $B H A R(5 Y)$ are one, two-, three-, and five-year market adjusted buy-and-hold abnormal returns. BHAR values are computed using equation (5).

The initial return, $B H A R(0)$, is $4.98 \%$ and significant at $1 \%$ level for the entire period. The median initial abnormal return is $2.07 \%$ and significant at $1 \%$ level according to Wilcoxon sign rank test. Mean values of BHAR(1M)- BHAR(6M) range between $4.78 \%-10,68 \%$ and mean values are all statistically significant. Median values of the same variables range between $-2.93 \%-1.28 \%$, which are statistically nor different from zero. Mean and median values of long-term BHARs are all negative. Mean values are not significant; however, median values are statistically significant. Table 3 shows that long-run returns are negative, but the huge difference between mean and median values indicates extreme values in the long-run returns. We believe that the insignificant negative values arise due to these extreme values.

Table 4. Summary of Market-Adjusted Buy-and-Hold Abnormal Returns (BHARs), Winsorized

\begin{tabular}{|c|c|c|c|c|c|c|c|}
\hline Variables & $\mathrm{N}$ & Mean & Median & Min. & Max. & t-Stat. & z-Stat. \\
\hline$B H A R(0)$ & 130 & $4.98 \% * * *$ & $2.07 \% * * *$ & $-17.20 \%$ & $31.47 \%$ & 6.23 & 4.88 \\
\hline$B H A R(1 M)$ & 130 & $4.61 \% * *$ & $-0.88 \%$ & $-37.83 \%$ & $102.29 \%$ & 2.28 & 0.66 \\
\hline$B H A R(3 M)$ & 129 & $8.63 \% * * *$ & $1.28 \%$ & $-49.50 \%$ & $102.29 \%$ & 2.72 & 1.40 \\
\hline$B H A R(6 M)$ & 127 & $7.30 \% *$ & $-2.93 \%$ & $-90.13 \%$ & $102.29 \%$ & 1.76 & 0.61 \\
\hline$B H A R(1 Y)$ & 123 & $-5.92 \%$ & $-10.89 \% *$ & $-99.38 \%$ & $102.29 \%$ & -1.40 & -1.77 \\
\hline$B H A R(2 Y)$ & 119 & $-15.68 \% * * *$ & $-21.46 \% * * *$ & $-100.98 \%$ & $102.29 \%$ & -3.12 & -3.12 \\
\hline$B H A R(3 Y)$ & 108 & $-24.14 \% * * *$ & $-43.38 \% * * *$ & $-100.98 \%$ & $102.29 \%$ & -3.85 & -3.26 \\
\hline$B H A R(5 Y)$ & 93 & $-31.17 \% * * *$ & $-57.68 \% * * *$ & $-100.98 \%$ & $102.29 \%$ & -4.48 & -3.39 \\
\hline
\end{tabular}


To get rid of these extreme values, we winsorize the BHARs $5 \%$ from each end (at $5^{\text {th }}$ and $95^{\text {th }}$ percentile values). The winsorize BHAR values are presented in Table 4 . Winsorization did not affect medians, however there are remarkable changes in mean values: Medium and long-run BHAR values decline and turn to be statistically significant. Winsorization limited minimum values at $-100.98 \%$ and maximum values at $102.29 \%$. We will use the winsorized values for the rest of this paper.

\subsection{Long-run Operational Performance of IPOs}

This section tests if our sample of IPOs have significant operational performance changes around IPO year. Following Chui et al., (2001), Wang (2005), Chi and Padget (2006), Chipeta and Jardine (2014), Arık and Mutlu (2015), and Kurtaran Çelik (2016), we compute the difference between financial ratios of consecutive years and run Wilcoxon sign rank test to check if the difference is significantly different from zero.

Summary of operating performance indicators and change in these indicators are presented in Table 5. Panel A reports summary of operating performance indicators. Median values of indicators are reported for seven years, three years before the IPO year (-3), the IPO year (0), and three years after the IPO year ( +3$)$. The first column documents number of available ratios for each year. Number of available ratios is lesser for earlier years. The median values are reported in the second column. Column 3 reports Wilcoxon sign rank test $z$-values for the annual changes in median values. The $z$-value demonstrates if the difference in medians between two consecutive years is significantly different from zero. The pattern in Panel A shows that earlier years (year -2 and -1 ) usually have positive changes for almost all indicators (z-values have positive signs). Starting from year 0 , differences turn to be negative. The negative values are significant for $A T, O M$, and $R O E$ for year (0); and for PM and ROE for the year (1), indicating a major decline in the IPO year and the following year.

Panel B of Table 5 reports changes in median values from year (-1) to following years. The first column after the "change in years" presents number of observations for each year. The second column displays the change in annual median values. And the last column documents Wilcoxon sign rank test z-values for the annual changes in median values. The pattern is a negative and significant change starting from year $(-1)$ and continuing through year (3) for all indicators. The mere insignificant decline belongs to $P M$ for year (-1), but it becomes significant in later years. This may indicate the change occurs slowly for this variable. These results show that indicator ratios sharply decline in the IPO year and keeps at lower levels at least for three years after the IPO. They do not increase to pre-IPO year values in the following few years. The significant decline in operational ratios is in line with the literature and may support windows of opportunity theory.

Table 5. Change in Performance Indicators before and after IPOs

\begin{tabular}{|c|c|c|c|c|c|c|c|}
\hline \multicolumn{4}{|c|}{$\begin{array}{l}\text { Panel A: Summary of Operating Performance } \\
\text { Indicators }\end{array}$} & \multicolumn{4}{|c|}{$\begin{array}{l}\text { Panel B: Summary of Change in Operating Performance } \\
\text { Indicators }\end{array}$} \\
\hline Years & $\mathrm{N}$ & Median & Z-Value & Change in Years & $\mathrm{N}$ & Median & Z-Value \\
\hline \multicolumn{8}{|l|}{$A T$} \\
\hline Year -3 & 39 & 0.94 & & & & & \\
\hline Year -2 & 70 & 0.81 & 0.38 & & & & \\
\hline Year -1 & 96 & 0.74 & 0.04 & & & & \\
\hline Year 0 & 116 & $0.64 * * *$ & -3.08 & From -1 to 0 & 99 & $-0.07 * * *$ & -3.08 \\
\hline Year 1 & 107 & 0.55 & -0.69 & From -1 to 1 & 86 & $-0.03 * *$ & -2.48 \\
\hline Year 2 & 101 & 0.63 & 0.33 & From -1 to 2 & 80 & $-0.03 * * *$ & -2.84 \\
\hline Year 3 & 100 & 0.62 & -1.04 & From -1 to 3 & 78 & $-0.07^{* *}$ & -2.51 \\
\hline \multicolumn{8}{|l|}{$O M$} \\
\hline Year -3 & 35 & 0.07 & & & & & \\
\hline Year -2 & 67 & $0.08 *$ & 1.87 & & & & \\
\hline Year -1 & 93 & $0.09 * *$ & 2.22 & & & & \\
\hline Year 0 & 116 & $0.08 * * *$ & -3.03 & From -1 to 0 & 94 & $-0.02 * * *$ & -3.03 \\
\hline Year 1 & 107 & 0.07 & -1.26 & From -1 to 1 & 83 & $-0.03 * * *$ & -4.04 \\
\hline Year 2 & 100 & 0.05 & -0.09 & From -1 to 2 & 77 & $-0.04 * * *$ & -2.92 \\
\hline Year 3 & 95 & 0.06 & 0.45 & From -1 to 3 & 72 & $-0.03 * * *$ & -2.82 \\
\hline
\end{tabular}


Long-Run Price and Operating Performance of Initial Public Offerings in Borsa Istanbul

Table 5. Change in Performance Indicators before and after IPOs (Continued)

\begin{tabular}{|c|c|c|c|c|c|c|c|}
\hline \multicolumn{4}{|c|}{$\begin{array}{l}\text { Panel A: Summary of Operating Performance } \\
\text { Indicators }\end{array}$} & \multicolumn{4}{|c|}{$\begin{array}{l}\text { Panel B: Summary of Change in Operating Performance } \\
\text { Indicators }\end{array}$} \\
\hline Years & $\mathrm{N}$ & Median & Z-Value & Change in Years & $\mathrm{N}$ & Median & Z-Value \\
\hline \multicolumn{8}{|l|}{$P M$} \\
\hline Year -3 & 35 & 0.03 & & & & & \\
\hline Year -2 & 67 & $0.03^{* *}$ & 2.11 & & & & \\
\hline Year -1 & 93 & 0.04 & 0.95 & & & & \\
\hline Year 0 & 116 & 0.05 & -0.55 & From -1 to 0 & 94 & -0.01 & -0.55 \\
\hline Year 1 & 107 & $0.04 *$ & -1.83 & From -1 to 1 & 83 & $-0.01 * *$ & -2.28 \\
\hline Year 2 & 100 & 0.03 & 0.59 & From -1 to 2 & 77 & $-0.03 * *$ & -2.45 \\
\hline Year 3 & 95 & 0.03 & -0.73 & From -1 to 3 & 72 & $-0.02 *$ & -1.89 \\
\hline \multicolumn{8}{|l|}{$R O E$} \\
\hline Year -3 & 39 & 0.08 & & & & & \\
\hline Year -2 & 70 & 0.08 & 0.35 & & & & \\
\hline Year -1 & 96 & 0.10 & -0.62 & & & & \\
\hline Year 0 & 116 & $0.07^{* *}$ & -2.45 & From -1 to 0 & 99 & $-0.03 * *$ & -2.45 \\
\hline Year 1 & 107 & $0.06 * *$ & -2.32 & From -1 to 1 & 86 & $-0.04 * * *$ & -2.81 \\
\hline Year 2 & 101 & 0.05 & -0.42 & From -1 to 2 & 80 & $-0.07 * * *$ & -2.98 \\
\hline Year 3 & 100 & 0.05 & -1.14 & From -1 to 3 & 78 & $-0.07 * * *$ & -3.14 \\
\hline
\end{tabular}

This table presents summary of operating performance indicators in Panel $A$, and summary of change in operating performance indicators from a year before the IPO in Panel B. Operating performance indicators are $A T, O M, P M$, and $R O E$. $A T$ is assets turnover ratio (total assets/net sales). OM is operating margin (EBIT/net sales). PM is profit margin (net income/net sales). ROE is return on equity (net income/shareholders' equity). Z-values are Wilcoxon sign rank test $z$ values. $* * * p<0.01, * * p<0.05, * p<0.1$

\subsection{Factors Impacting Long-run IPO Returns}

This section looks for factors that can have a significant relation with the long-run returns of IPOs. Initial abnormal returns, real proceeds, real money left on the table, or hot/cold periods can be possible factors in relation with negative returns. The following model is used to determine the relationship between long-run IPO returns and independent variables.

$$
\operatorname{BHAR}(3 Y)_{i}=\alpha+\beta . X_{i}+\theta \cdot D_{O}+\gamma_{t}+\varepsilon_{i}
$$

where $B H A R(3 Y)$ is the 3-year BHAR values. We use $B H A R(3 Y)$ as a proxy for long-run abnormal returns of IPOs because it is the most widely used proxy in the literature. We run the same model for $B H A R(5 Y)$ and find similar results; however, we do not present those results to save space. $\mathrm{X}_{\mathrm{i}}$ is $A R$, proceeds, money_left, MarCap, Cap-Ratio, $D_{H}, A T, O M, P M$, or ROE, alternatively. $D_{0}$ is added to the model to control for high-level capital increases. Capital increases would inflate shareholders' equity and total assets in the IPO year; however, sales or earnings would not inflate as much. As a result, a decline in $A T$ and $R O E$ is unavoidable if IPOs inject capital to the company. Current shareholders' sales would not inject capital, thus would not affect ratios. To control for high and low level capital injections, we include $D_{o}$ in our model. $\delta_{t}$ represents year fixed effects, $\varepsilon_{\mathrm{i}}$ is the error term.

The bivariate regression results are presented in Table 6. Proceeds, MarCap, $D_{H}$, Cap-ratio, AT and $R O E$ are the significant factors in association with long-run IPO returns. Proceeds and MarCap have a positive relation with long-run returns while $D_{H}$, Cap-ratio, $A T$, and $R O E$ have a negative relation with long-run returns. Capital increases are controlled in all specifications. We can interpret these results as follows: Large IPOs or IPOs of large companies are expected to have higher long-run returns. IPOs made in hot issue periods, or IPOs with larger capital surges, or IPOs of firms with higher AT or ROE ratios are likely to generate lower longrun returns. 
is as follows:

Next, we run multiple regressions using only significant variables in univariate regressions. The model

$$
\operatorname{BHAR}_{(3 Y)_{i}}=\alpha+\beta_{1} . \text { IPO_specific } i+\beta_{2} . \text { Performance } i+\beta_{3} . D o_{i}+\gamma_{t}+\varepsilon_{i}
$$

where $B H A R(3 Y)_{i}$ represents three-year BHARs for stock i, IPO-specific variables are proceeds, MarCap, $D_{H}$, and Cap-ratio, Performance variables are $A T_{t}$, and $R O E_{t}$ alternatively. We do not use performance variables in the same model due to high correlation between them. $\delta_{t}$ represents year fixed effects, $\varepsilon_{\mathrm{i}}$ is the error term.

Table 6. Bivariate Regressions of Long-run BHARs and IPO Characteristics

\begin{tabular}{|c|c|c|c|c|c|c|c|c|c|c|}
\hline Variables & $B H A R(3 Y)$ & $B H A R(3 Y)$ & $B H A R(3 Y)$ & $B H A R(3 Y)$ & $B H A R(3 Y)$ & $B H A R(3 Y)$ & $B H A R(3 Y)$ & $B H A R(3 Y)$ & $B H A R(3 Y)$ & $B H A R(3 Y)$ \\
\hline Money_left & $\begin{array}{l}-0.00 \\
(-0.13)\end{array}$ & & & & & & & & & \\
\hline Proceeds & & $\begin{array}{l}0.00^{* *} \\
(2.11)\end{array}$ & & & & & & & & \\
\hline MarCap & & & $\begin{array}{l}0.00^{*} \\
(1.69)\end{array}$ & & & & & & & \\
\hline$A R$ & & & & $\begin{array}{l}1.81 \\
(1.10)\end{array}$ & & & & & & \\
\hline$D_{H}$ & & & & & $\begin{array}{l}-0.34 * * \\
(-2.54)\end{array}$ & & & & & \\
\hline Cap-Ratio & & & & & & $\begin{array}{l}-0.52^{* *} \\
(-2.37)\end{array}$ & & & & \\
\hline$A T$ & & & & & & & $\begin{array}{l}-0.01^{* * *} \\
(-5.35)\end{array}$ & & & \\
\hline$O M$ & & & & & & & & $\begin{array}{l}0.00 \\
(0.67)\end{array}$ & & \\
\hline$P M$ & & & & & & & & & $\begin{array}{l}0.00 \\
(0.65)\end{array}$ & \\
\hline ROE & & & & & & & & & & $\begin{array}{l}-0.02^{* * *} \\
(-3.88)\end{array}$ \\
\hline Do & $\begin{array}{l}0.13 \\
(0.99)\end{array}$ & $\begin{array}{l}0.15 \\
(1.23)\end{array}$ & $\begin{array}{l}0.14 \\
(1.11)\end{array}$ & $\begin{array}{l}0.12 \\
(0.95)\end{array}$ & $\begin{array}{l}0.15 \\
(1.19)\end{array}$ & $\begin{array}{l}0.39 * * \\
(2.39)\end{array}$ & $\begin{array}{l}0.13 \\
(1.02)\end{array}$ & $\begin{array}{l}0.16 \\
(1.19)\end{array}$ & $\begin{array}{l}0.16 \\
(1.19)\end{array}$ & $\begin{array}{l}0.12 \\
(0.92)\end{array}$ \\
\hline Constant & $\begin{array}{l}-0.39^{* *} \\
(-2.40)\end{array}$ & $\begin{array}{l}-0.54^{* * *} \\
(-3.57)\end{array}$ & $\begin{array}{l}-0.49^{* * *} \\
(-3.11)\end{array}$ & $\begin{array}{l}-0.39^{* *} \\
(-2.43)\end{array}$ & $\begin{array}{l}-0.16 \\
(-0.83)\end{array}$ & $\begin{array}{l}-0.16 \\
(-0.81)\end{array}$ & $\begin{array}{l}-0.39^{* *} \\
(-2.48)\end{array}$ & $\begin{array}{l}-0.40^{* *} \\
(-2.55)\end{array}$ & $\begin{array}{l}-0.40^{* *} \\
(-2.55)\end{array}$ & $\begin{array}{l}-0.39 * * \\
(-2.47)\end{array}$ \\
\hline Observations & 108 & 108 & 108 & 108 & 108 & 108 & 101 & 101 & 101 & 101 \\
\hline Year FE & YES & YES & YES & YES & YES & YES & YES & YES & YES & YES \\
\hline Adjusted R2 & 0.07 & 0.11 & 0.08 & 0.08 & 0.14 & 0.10 & 0.09 & 0.06 & 0.06 & 0.08 \\
\hline
\end{tabular}

This table presents bivariate regression coefficients of BHAR(3Y). BHAR(3Y) is the buy-and-hold returns for three years after the IPO. Proceeds are real aggregate gross proceeds with 2019 numbers. Proceeds are computed as number of issues sold multiplied by sales price at the offer market. Money_left is real aggregate money-left on the table with 2019 numbers. Money_left is computed as multiplying number of shares offered by the difference between first trading day close price and the offer price. MarCap is the market capitalization on the offer date. $A R$ is the initial abnormal return. Initial return is the return from offer price to the first public trading day closing price. $A R$ is computed as subtracting market return (BIST100 index return) from the initial return. $D_{H}$ is a dummy variable that takes the value of 1 if the IPO is made in a hot issue period, 0 otherwise. Cap-ratio is capital increase ratio, which is the ratio of capital increased through the IPO to the total capital. $D_{O}$ is a dummy variable that takes the value of 1 if capital increase ratio is above the median value, 0 otherwise. Capital increase ratio is computed as the ratio of capital increased through the IPO divided by the total capital. $A T$ is assets turnover ratio (total assets/net sales). OM is operating margin (EBIT/net sales). PM is profit margin (net income/net sales). ROE is return on equity (net income/shareholders' equity). Regressions control for year fixed effects. Robust t-statistics in parentheses. ${ }^{* * *} \mathrm{p}<0.01, * * \mathrm{p}<0.05, * \mathrm{p}<0.1$ 
Multivariate regression results on long-run abnormal returns are presented in Table 7. The first three columns employ AT as performance variable. The first column includes all variables significant in the previous table. Proceeds, Dh, Cap-ratio, and AT continue being significant while MarCap is not significant in this model. The second column drops the MarCap variable. All variables are significant in the second column. The third column drops $D_{O}$. Results indicate that $A T, D H$, and proceeds are significant in all specifications. The size variable, MarCap, is not significant in any specifications. Cap_ratio is significant only for companies with high ownership ratio.

The last three columns in Table 7 employs ROE as performance variable. The fourth column includes all variables while the fifth column includes variables significant in the fourth column. And the last column drops $D o$. The coefficients in the fourth and the fifth columns indicate that the relation between long-run abnormal returns and ROE is not strong when controlled for capital surges. Capital surges weakens the relation between ROE and long-run abnormal returns of IPOs. When we do not control for the capital surges (the last column), the relationship is negative and significant. Moreover, we observe a strong negative relation between long-run abnormal returns and Proceeds and $D_{H}$.

Table 7. Univariate Regressions of Long-run BHARs and Long-run Performance Indicators

\begin{tabular}{|c|c|c|c|c|c|c|}
\hline Variables & $\operatorname{BHAR}(3 \mathrm{Y})$ & $\operatorname{BHAR}(3 \mathrm{Y})$ & $\operatorname{BHAR}(3 \mathrm{Y})$ & $\operatorname{BHAR}(3 Y)$ & $\operatorname{BHAR}(3 \mathrm{Y})$ & $\operatorname{BHAR}(3 \mathrm{Y})$ \\
\hline \multirow[t]{2}{*}{ Proceeds } & $0.00 *$ & $0.00 * *$ & $0.00 * *$ & $0.00 *$ & $0.00 * *$ & $0.00 * *$ \\
\hline & (1.92) & $(2.34)$ & $(2.28)$ & (1.92) & $(2.33)$ & $(2.29)$ \\
\hline \multirow[t]{2}{*}{ MarCap } & -0.00 & & -0.00 & -0.00 & & -0.00 \\
\hline & $(-0.95)$ & & $(-1.56)$ & $(-0.94)$ & & $(-1.55)$ \\
\hline \multirow[t]{2}{*}{$D_{H}$} & $-0.26 *$ & $-0.28 * *$ & $-0.25 *$ & $-0.27^{*}$ & $-0.28 * *$ & $-0.25 *$ \\
\hline & $(-1.88)$ & $(-2.00)$ & $(-1.76)$ & $(-1.90)$ & $(-2.00)$ & $(-1.77)$ \\
\hline \multirow[t]{2}{*}{ Cap-Ratio } & $-0.45^{*}$ & $-0.48 * *$ & -0.00 & $-0.45^{*}$ & $-0.50 * *$ & -0.01 \\
\hline & $(-1.90)$ & $(-2.10)$ & $(-0.02)$ & $(-1.85)$ & $(-2.11)$ & $(-0.05)$ \\
\hline \multirow[t]{2}{*}{$A T$} & $-0.00 * * *$ & $-0.00 * * *$ & $-0.00 * * *$ & & & \\
\hline & $(-2.99)$ & $(-2.92)$ & $(-4.59)$ & & & \\
\hline \multirow[t]{2}{*}{$R O E$} & & & & $-0.01 *$ & 0.02 & $-0.02 * * *$ \\
\hline & & & & $(-1.77)$ & (1.09) & $(-4.02)$ \\
\hline \multirow[t]{2}{*}{ Do } & $0.40 * *$ & $0.41 * *$ & & $0.40 * *$ & $0.43 * *$ & \\
\hline & $(2.31)$ & $(2.43)$ & & $(2.18)$ & $(2.35)$ & \\
\hline \multirow[t]{2}{*}{ Constant } & -0.12 & -0.11 & -0.26 & -0.12 & -0.10 & -0.26 \\
\hline & $(-0.48)$ & $(-0.45)$ & $(-1.16)$ & $(-0.47)$ & $(-0.42)$ & $(-1.15)$ \\
\hline Observations & 101 & 101 & 101 & 101 & 101 & 101 \\
\hline Year FE & YES & YES & YES & YES & YES & YES \\
\hline Adjusted R2 & 0.161 & 0.167 & 0.129 & 0.155 & 0.159 & 0.125 \\
\hline
\end{tabular}

This table provides multiple regression coefficients of BHAR(3Y). BHAR(3Y) is the buy-and-hold returns for three years after the IPO. Proceeds are real aggregate gross proceeds with 2019 numbers. Proceeds are computed as number of issues sold multiplied by sales price at the offer market. MarCap is the market capitalization on the offer date. $D_{H}$ is a dummy variable that takes the value of 1 if the IPO is made in a hot issue period, 0 otherwise. Cap-ratio is capital increase ratio, which is the ratio of capital increased through the IPO to the total capital. $A T$ is assets turnover ratio (total assets/net sales). ROE is return on equity (net income/shareholders' equity). $D_{O}$ is a dummy variable that takes the value of 1 if capital increase ratio is above the median value, 0 otherwise. Regressions control for year fixed effects. Robust t-statistics in parentheses. ${ }^{* * *} p<0.01,{ }^{* *} p<0.05,{ }^{*} p<0.1$

Table 7, overall, indicates that performance indicators play an important role in the making of longrun abnormal returns. The coefficients of performance indicators are negative, indicating issuing firms with high asset turnover and equity efficiency will result in lower abnormal returns in the long-term. The higher the asset and equity efficiency of the firm, the more severe it will underperform in the long-term. One explanation can be "window dressing", which explains the superiority of financial performance indicators around IPO year as earnings management. It claims managers have an incentive to manage earnings prior to issue in order to make company financial tables attractive for prospective investors (Aharony, Lin, \& Loeb, 1993; Teoh, Welch, \& Wong, 1998a, 1998b; Teoh, Wong, \& Rao, 1998; Chui et al., 2001). This study does not 
analyze the integrity of accounting records; however, there is room to analyze records for further research. This table also emphasizes the earlier findings of this paper: Issuing in a hot period has negative relation with long-term returns. IPOs realized in hot periods have lower long-term returns, in other words, they underperform more in the long-term. Proceeds have a positive relationship with $B H A R(3 Y)$, suggesting that larger IPOs underperform less.

\subsection{Long-run Price Performance and Long-run Operational Performance}

An important question would arise whether the relation between long-run abnormal returns and performance indicators is temporal. To discover the relationship between long-run returns and performance indicators, first, we run model (9) altering dependent variables with $A T, O M, P M$, and $R O E$ variables and their three year lagged and three year fort values.

Bivariate regression coefficients and robust standard errors are presented in Table 8. The first two columns report regression coefficients and t-statistics for performance indicators. The next two columns report regression coefficients for Do and the regression constant. T-statistics of these variables are not reported to save space; however, their significance levels are marked with $\left({ }^{*}\right)$. Each specification has only one performance variable due to potential multicollinearity. Do is added in every model to control for capital surges. We also run univariate models excluding $D_{0}$. The sign and significance of the operating variables are similar; however, we do not report this table to save space.

Results show that contemporaneous, lagged, and fort values of AT and ROE are all negative and significant while contemporaneous, lagged, and fort values $\mathrm{OM}$ and $\mathrm{PM}$ are not in relation with long-run abnormal returns. As a result, AT and ROE, irrespective of whenever they are measured, have a reverse relation with long-run IPO abnormal returns. The higher the AT and ROE are, the lower the long-run abnormal returns. These results show that the relation between long-run abnormal returns and performance indicators are not temporal.

\section{Robustness Tests}

This study computes CARs and WRs to satisfy the curiosity about their outcomes. CARs, BHARs, and WRs are used alternatively in the literature. CARs are preferred for short-term event studies because they are biased in longer-term analyses (Conrad \& Kaul, 1993). BHARs and WRs are used for representing longerterm abnormal returns. It is documented before that WRs do not have such a bias similar to CARs because they are equal to BHARs in testing time series return equal across the IPO and market (Bessembinder \& Zhang, 2013).

Table 8. Univariate Regressions of Long-run BHARs and Long-run Performance Indicators

\begin{tabular}{lccccccc}
\hline Variables & BHAR(3Y) & t-Statistic & Do & Constant & Obs & Year FE & Adjusted R2 \\
\hline AT(-3) & $-0.00^{*}$ & $(-2.06)$ & 0.11 & -0.24 & 27 & YES & -0.0356 \\
OM(-3) & 0.44 & $(0.96)$ & $0.81^{* * *}$ & $-0.75^{* * *}$ & 23 & YES & 0.288 \\
PM(-3) & $0.28^{* * *}$ & $(3.46)$ & $0.91^{* * *}$ & $-0.78^{* * *}$ & 23 & YES & 0.376 \\
ROE(-3) & $-0.00^{*}$ & $(-2.03)$ & 0.38 & -0.24 & 27 & YES & -0.04 \\
AT(-2) & $-0.00^{* * *}$ & $(-3.48)$ & 0.11 & $-0.45^{* *}$ & 56 & YES & 0.06 \\
OM(-2) & $0.03^{* * *}$ & $(3.48)$ & 0.21 & $-0.45^{* *}$ & 53 & YES & 0.04 \\
PM(-2) & 0.02 & $(0.53)$ & 0.19 & $-0.45^{* *}$ & 53 & YES & 0.02 \\
ROE(-2) & $-0.01^{* * *}$ & $(-3.56)$ & 0.11 & $-0.45^{* *}$ & 56 & YES & 0.06 \\
AT(-1) & $-0.00^{* * *}$ & $(-3.47)$ & 0.23 & $-0.52^{* * *}$ & 80 & YES & 0.12 \\
OM(-1) & 0.01 & $(0.67)$ & 0.22 & $-0.60^{* * *}$ & 77 & YES & 0.11 \\
PM(-1) & 0.02 & $(1.12)$ & 0.23 & $-0.61 * * *$ & 77 & YES & 0.12 \\
ROE(-1) & $-0.02^{* * *}$ & $(-2.73)$ & 0.22 & $-0.54^{* * *}$ & 80 & YES & 0.11 \\
AT(+1) & $-0.01^{* * *}$ & $(-4.47)$ & 0.14 & $-0.39 * *$ & 101 & YES & 0.09 \\
OM(+1) & 0.02 & $(0.85)$ & 0.16 & $-0.41^{* *}$ & 101 & YES & 0.06 \\
PM(+1) & 0.02 & $(0.61)$ & 0.16 & $-0.41^{* *}$ & 101 & YES & 0.06 \\
ROE(+1) & $-0.03^{* *}$ & $(-2.42)$ & 0.13 & $-0.39 * *$ & 101 & YES & 0.08
\end{tabular}


Long-Run Price and Operating Performance of Initial Public Offerings in Borsa Istanbul

Table 8. Univariate Regressions of Long-run BHARs and Long-run Performance Indicators

\begin{tabular}{lccccccc}
\hline Variables & BHAR(3Y) & t-Statistic & Do & Constant & Obs & Year FE & Adjusted R2 \\
\hline AT $(+2)$ & $-0.00^{* * *}$ & $(-5.25)$ & 0.13 & $-0.39^{* *}$ & 100 & YES & 0.10 \\
OM(+2) & 0.17 & $(0.76)$ & 0.18 & $-0.43^{* * *}$ & 99 & YES & 0.08 \\
PM(+2) & 0.02 & $(0.26)$ & 0.15 & $-0.41^{* *}$ & 99 & YES & 0.07 \\
ROE $(+2)$ & $-0.01 * * *$ & $(-4.03)$ & 0.12 & $-0.39 * *$ & 100 & YES & 0.14 \\
AT $(+3)$ & $-0.00^{* * *}$ & $(-4.48)$ & 0.13 & $-0.39 * *$ & 99 & YES & 0.09 \\
OM(+3) & 0.06 & $(0.46)$ & 0.17 & $-0.44 * * *$ & 95 & YES & 0.08 \\
PM $(+3)$ & $0.13^{* *}$ & $(2.49)$ & 0.17 & $-0.42^{* * *}$ & 95 & YES & 0.11 \\
ROE $(+3)$ & $-0.00^{* * *}$ & $(-4.38)$ & 0.13 & $-0.39 * *$ & 99 & YES & 0.08 \\
\hline
\end{tabular}

This table provides regression coefficients between BHAR(3Y) and contemporaneous performance indicators in Panel $A$, and lagged performance indicators in Panel B, and fort performance indicators in Panel C. Operating performance indicators are $A T, O M, P M$, and ROE. $A T$ is assets turnover ratio (total assets/net sales). $O M$ is operating margin (EBIT/net sales). $P M$ is profit margin (net income/net sales). ROE is return on equity (net income/shareholders' equity). $D_{O}$ is a dummy variable that takes the value of 1 if capital increase ratio is above the median value, 0 otherwise. Regressions control for year fixed effects. Robust t-statistics in parentheses. ${ }^{* * *} p<0.01,{ }^{* *} p<0.05,{ }^{*} p<0.1$

Table 9 presents winsorized WRs for the $5^{\text {th }}$ and $95^{\text {th }}$ percentiles. Since $W R s$ are ratios, they represent positive returns if their values are greater than 1 . Mean values are greater than for one year and shorterterm returns, mean values are less than one for two-years and longer-run returns. Median values follow a similar pattern. Mean and median values of longer than one-year returns are significantly negative. Long-run WR results support BHAR results with negative significant long-run abnormal returns.

Table 9. Summary of Wealth Relatives (BHARs), Winsorized

\begin{tabular}{lccccccc}
\hline Variable & $\mathrm{N}$ & Mean & Median & Min. & Max. & t-Stat & Z-Stat. \\
\hline WR $(0)$ & 130 & $1.05^{* * *}$ & $1.02^{* * *}$ & 0.83 & 1.35 & 6.21 & 4.90 \\
WR(1M) & 130 & $1.04^{* *}$ & 0.99 & 0.63 & 1.84 & 2.37 & 0.76 \\
WR(3M) & 129 & $1.09^{* * *}$ & 1.02 & 0.56 & 1.84 & 2.88 & 1.58 \\
WR(6M) & 127 & $1.07^{*}$ & 0.97 & 0.28 & 1.84 & 1.87 & 0.81 \\
WR(1Y) & 123 & 0.96 & 0.89 & 0.27 & 1.84 & -1.05 & -1.48 \\
WR(2Y) & 119 & $0.88^{* * *}$ & $0.83^{* * *}$ & 0.27 & 1.84 & -2.84 & -2.88 \\
WR(3Y) & 108 & $0.82^{* * *}$ & $0.63^{* * *}$ & 0.27 & 1.84 & -3.52 & -3.01 \\
WR(5Y) & 93 & $0.79^{* * *}$ & $0.57^{* * *}$ & 0.27 & 1.84 & -4.01 & -3.33 \\
\hline
\end{tabular}

$W R(0)$ is initial wealth relative. $W R(1 M), W R(3 M)$, and $W R(6 M)$ are one-, three-, and six-month wealth relatives, respectively. $W R(1 Y), W R(2 Y), W R(3 Y)$, and $W R(5 Y)$ are one-, two-, three-, and five-year wealth relatives. WR values are computed using equation (7). WR values are winsorized at their $5^{\text {th }}$ and $95^{\text {th }}$ percentiles.

Table 10. Summary of Cumulative Abnormal Returns (CARs), Winsorized

\begin{tabular}{lccccccc}
\hline Variables & $\mathrm{N}$ & Mean & Median & Min. & Max. & t-Stat & Z-Stat. \\
\hline CAR(0) & 130 & $4.98 \% * * *$ & $2.07 \% * * *$ & $-17.20 \%$ & $31.47 \%$ & 6.23 & 4.88 \\
CAR(1M) & 130 & $4.10 \% * * *$ & $-0.64 \%$ & $-37.03 \%$ & $85.28 \%$ & 2.29 & 1.01 \\
CAR(3M) & 129 & $7.71 \% * * *$ & $3.16 \% *$ & $-53.87 \%$ & $109.91 \%$ & 2.69 & 1.86 \\
CAR(6M) & 127 & $7.08 \% *$ & $0.22 \%$ & $-92.23 \%$ & $109.91 \%$ & 1.86 & 1.20 \\
CAR(1Y) & 123 & $-0.85 \%$ & $-0.64 \%$ & $-92.23 \%$ & $109.91 \%$ & -0.19 & -0.41 \\
CAR(2Y) & 119 & $-5.57 \%$ & $-7.08 \%$ & $-92.23 \%$ & $109.91 \%$ & -1.08 & -1.21 \\
CAR(3Y) & 108 & $-8.00 \%$ & $-15.84 \%$ & $-92.23 \%$ & $109.91 \%$ & -1.26 & -1.21 \\
CAR(5Y) & 93 & $1.81 \%$ & $-3.54 \%$ & $-92.23 \%$ & $109.91 \%$ & 0.27 & 0.14 \\
\hline
\end{tabular}

$\operatorname{CAR}(0)$ is initial cumulative abnormal return. $C A R(1 M), C A R(3 M)$, and $C A R(6 M)$ are one-, three-, and six-month cumulative abnormal returns, respectively. $C A R(1 Y), C A R(2 Y), C A R(3 Y)$, and $C A R(5 Y)$ are one-, two-, three-, and fiveyear cumulative abnormal returns. CAR values are computed using equation (8). CAR values are winsorized at their $5^{\text {th }}$ and $95^{\text {th }}$ percentiles. 
Table 10 presents winsorized CARs for the $5^{\text {th }}$ and $95^{\text {th }}$ percentiles. Initial return and mid-term wealth relatives have significantly positive signs. The sign of long-run returns is negative; however, both the mean and median long-run CARs are insignificant. Moreover, the CAR(5Y) is positive. These results support the (Conrad \& Kaul, 1993) argument of upward bias in long-run CARs compared to long-run BHARs and WRs. CAR results deviate from BHAR results in the long-term.

\section{Conclusion}

This paper analyzes long-run price performance and operational performance of IPOs between 2010 and 2019 in Borsa Istanbul. Long-run price performance of issuing companies are computed using buy-andhold abnormal returns, wealth relatives and cumulative abnormal returns. Even though cumulative abnormal returns provide weaker results, all methods indicate negative long-run abnormal returns for IPOs. Results show that large IPOs have higher returns in the long-term. Moreover, IPOs made in hot issue periods will underperform more. This finding is in line with "windows of opportunity theory" of long-run returns of IPOs.

We measure long-run operating performance by testing the difference between the values of performance indicators in two consecutive years. The median values of financial indicators decline after the IPO year. We find that performance indicators decline significantly during and after the IPO year and keep at low levels for the next three years. These results are in line with windows of opportunity theory: If IPOs are substantiated in overvaluation periods, issuing firms cannot continue their recent superior operational performance and end up with long-run underperformance (Ritter, 1991; Loughran \& Ritter, 1995, 1997; Cai \& Wei, 1997; Pástor \& Veronesi, 2005; Pástor et al., 2009).

Lastly, multivariate regressions demonstrate that long-run returns are negatively related to some performance indicators, namely asset turnover and return on equity. These two indicators are efficiency measures of assets and equity. The higher the asset and equity efficiency of a company around IPO year, the more underperforms its price in the coming three years. Multiple regressions also emphasize the significantly negative relation between long-run returns and the hot period dummy variable, suggesting IPOs carried out in hot issue periods underperform more in the long-term. The same models underline the positive relation between proceeds and long-run abnormal returns.

This paper aims to help investors make more educated decisions about their portfolio choices of equity through long-run effects of IPOs on issuing firms. It can also help regulators in policy making about equity markets. With the light of this information, long-run IPO performances can be better predicted and IPO timing can be better scheduled. Further research can focus on reasons of the dual underperformance of price and operations and search more about their connections.

\section{Declarations and Disclosures}

Ethical Responsibilities of Authors: The author of this article confirms that her work complies with the principles of research and publication ethics.

Conflicts of Interest: No potential conflict of interest was reported by the author.

Funding: The author received no financial support for the preparation and/or publication of this article.

Author Contributions: The author confirms sole responsibility for conceptualization and design, data collection, analysis of data and interpretation of results, writing the first draft of the manuscript, and review and editing.

Plagiarism Checking: This article was screened for potential plagiarism using a plagiarism screening program. 


\section{End Notes}

1. https://datastore.borsaistanbul.com/

2. https://www.spk.gov.tr/Sayfa/AltSayfa/895

3. Inflation calculator: http://www3.tcmb.gov.tr/enflasyoncalc/enflasyon_anayeni.php

\section{References}

Affleck-Graves, J., Hegde, S., \& Miller, R. E. (1996). Conditional price trends in the aftermarket for initial public offerings. Financial Management, 25(4), 25-40.

Aharony, J., Lin, C. J., \& Loeb, M. P. (1993). Initial public offerings, accounting choices, and earnings management. Contemporary Accounting Research, 10(1), 61-81.

Arık, E., \& Mutlu, E. (2015). Post-initial public offering operating performance and its determinants: Initial public offering characteristics and corporate governance practices. Emerging Markets Finance and Trade, 51(sup2), 62-83.

Ayden, T., \& Karan, M. B. (2000). İstanbul Menkul Kıymetler Borsası'nda ilk halka arzların uzun vadeli fiyat performanslarının ölçülmesi. Gazi Üniversitesi iiBF Dergisi, 3, 87-96.

Balatbat, M. C. A., Taylor, S. L., \& Walter, T. S. (2004). Corporate governance, insider ownership and operating performance of Australian initial public offerings. Accounting and Finance, 44(3), 299-328.

Barber, B. M., \& Lyon, J. D. (1997). Detecting long-run abnormal stock returns: The empirical power and selection of test statistics. Journal of Financial Economics, 43, 341-372.

Bessembinder, H., \& Zhang, F. (2013). Firm characteristics and long-run stock returns after corporate events. Journal of Financial Economics, 109(1), 83-102.

Bildik, R., \& Yılmaz, M. K. (2008). The market performance of initial public offerings in the Istanbul Stock Exchange. BDDK Bankacılık ve Finansal Piyasalar, 2(2), 49-75.

Brav, A., Geczy, C., \& Gompers, P. A. (2000). Is the abnormal return following equity issuances anomalous? Journal of Financial Economics, 56(2), 209-249.

Cai, J., \& Wei, K. C. J. (1997). The investment and operating performance of Japanese initial public offerings. PacificBasin Finance Journal, 5(4), 389-417.

Carter, R. B., Dark, F. H., Floros, I. V., \& Sapp, T. R. A. (2011). Characterizing the risk of IPO long-run returns: The impact of momentum, liquidity, skewness, and investment. Financial Management, 40(4), 1067-1086.

Carter, R. B., Dark, F. H., \& Singh, A. K. (1998). Underwriter reputation, initial returns, and the long-run performance of IPO stocks. The Journal of Finance, 53(1), 285-311.

Chi, J., \& Padgett, C. (2006). Operating performance and its relationship to market performance of chinese initial public offerings. The Chinese Economy, 39(5), 28-50.

Chipeta, C., \& Jardine, A. (2014). A review of the determinants of long run share price and operating performance of initial public offerings on the Johannesburg Stock Exchange. The International Business \& Economics Research Journal, 13(5), 1161-1176.

Chui, A. P. L., Lau, H. F. W., \& Ip, Y. K. (2001). The post-issue performance of initial public offering firms in the People's Republic of China. Advances in International Accounting, 14, 75-100.

Conrad, J., \& Kaul, G. (1993). Long-term market overreaction or biases in computed returns? Journal of Finance, 48(1), 39-63.

Dong, M., Michel, J. S., \& Pandes, J. A. (2011). Underwriter quality and long-run IPO performance. Financial Management, 40(1), 219-251.

Eckbo, B. E., \& Norli, $\varnothing$. (2005). Liquidity risk, leverage and long-run IPO returns. Journal of Corporate Finance, 11(1), 135.

Gao, Y., Mao, C. X., \& Zhong, R. (2006). Divergence of opinion and long-term performance of initial public offerings. Journal of Financial Research, 29(1), 113-129.

Gompers, P., \& Lerner, J. (2000). Money chasing deals? The impact of fund inflows on private equity valuations. Journal of Financial Economics, 55(2), 281-325.

Helwege, J., \& Liang, N. (2004). Initial public offerings in hot and cold markets. The Journal of Financial and Quantitative Analysis, 39(3), 541-569. 
Houge, T., Loughran, T., Suchanek, G., \& Yan, X. (2001). Divergence of opinion, uncertainty, and the quality of initial public offerings. Financial Management, 30(4), 5-23.

Ibbotson, R. (1975). Price performance of common stock new issues. Journal of Financial Economics, 2, $235-272$.

Jain, B. A., \& Kini, O. (1994). The post-issue operating performance of IPO firms. The Journal of Finance, 49(5), 16991726.

Kaya, T. (2017). Borsa İstanbul'da ilk halka arzların uzun dönem performans analizi: Normalüstü getiri mümkün mü? Ekonomi Politika ve Finans Araştırmaları Dergisi, 2(1), 6-19.

Kırkkulak, B. (2010). Uzun dönemli al-ve-tut getirileri: iMKB'de halka açık şirketler üzerine bir uygulama. Ege Akademik Bakış Dergisi, 10(2), 465-486.

Korajczyk, R. A., Lucas, D. J., \& McDonald, R. L. (1991). The effect of information releases on the pricing and timing of equity issues. The Review of Financial Studies, 4(4), 685-708.

Kurtaran Çelik, M. (2016). Firmaların ilk halka arz sonrası faaliyet performanslarının değerlendirilmesi: Borsa İstanbul örneği. International Journal of Management Economics and Business, 12(27), 267-282.

Kurtaran, A., \& Er, B. (2008). The post-issue operating performance of IPOs in an emerging market: Evidence from Istanbul Stock Exchange. Investment Management and Financial Innovations, 5(4), 50-62.

Loughran, T. (1993). NYSE vS NASDAQ returns: Market microstructure or the poor performance of initial public offerings? Journal of Financial Economics, 33(2), 241-260.

Loughran, T., \& Ritter, J. R. (1995). The new issues puzzle. The Journal of Finance, 50(1), 23-51.

Loughran, T., \& Ritter, J. R. (1997). The operating performance of firms conducting seasoned equity offerings. The Journal of Finance, 52(5), 1823-1850.

Loughran, T., Ritter, J. R., \& Rydqvist, K. (1994). Initial public offerings: International insights. Pacific-Basin Finance Journal, 3(1), 139-140.

Lyandres, E., Le, S., \& Zhang, L. (2008). The new issues puzzle: Testing the investment-based explanation. The Review of Financial Studies, 21(6), 2825-2855.

Pástor, L. U., Taylor, L. A., \& Veronesi, P. (2009). Entrepreneurial learning, the IPO decision, and the post-IPO drop in firm profitability. The Review of Financial Studies, 22(8), 3005-3046.

Pástor, L. u., \& Veronesi, P. (2005). Rational IPO waves. The Journal of Finance, 60(4), 1713-1757.

Purnanandam, A. K., \& Swaminathan, B. (2004). Are IPOs really underpriced? The Review of Financial Studies, 17(3), 811-848

Ritter, J. R. (1991). The long-run performance of initial public offerings. The Journal of Finance, 46(1), 3-27.

Ritter, J. R., \& Welch, I. (2002). A review of IPO activity, pricing, and allocations. The Journal of Finance, 57(4), 17951828.

Schultz, P. (2003). Pseudo market timing and the long-run underperformance of IPOs. The Journal of Finance, 58(2), 483517.

Spiess, D. K., \& Affleck-Graves, J. (1995). Underperformance in long-run stock returns following seasoned equity offerings. Journal of Financial Economics, 38(3), 243-267.

Stoll, H. R., \& Curley, A. J. (1970). Small business and the new issues market for equities. Journal of Financial \& Quantitative Analysis, 5(3), 309-322.

Teoh, S. H., Welch, I., \& Wong, T. J. (1998a). Earnings management and the long-run market performance of initial public offerings. The Journal of Finance, 53(6), 1935-1974.

Teoh, S. H., Welch, I., \& Wong, T. J. (1998b). Earnings management and the underperformance of seasoned equity offerings. Journal of Financial Economics, 50(1), 63-99.

Teoh, S. H., Wong, T. J., \& Rao, G. R. (1998). Are accruals during initial public offerings opportunistic? Review of Accounting Studies, 3(1), 175-208.

Turan Kurtaran, A. (2013). Türkiye'deki ilk halka arzların ilk getirileri ile uzun dönem fiyat performansları arasındaki ilişkinin analizi. International Journal of Economic and Administrative Studies, 6(11), 185-209.

Tükel, A. (2010). Asimetrik enformasyon ışığında halka arzların uzun dönemli performanslarının değerlendirilmesi. Ekonometri ve Istatistik, 12, 102-121.

Tütüncü, L., \& Uzunel, V. (2020). Measuring IPO performance through industry-adjusted models. Finansal Araştırmalar ve Çalışmalar Dergisi, 12(23), 639-652. 
Ünlü, U. (2006). Türkiye'de ilk defa halka arz edilen bankacılık sektörü hisse senetlerinin uzun dönem fiyat performansları. Erciyes Üniversitesi Iktisadi ve Idari Bilimler Fakültesi Dergisi, 27, 119-147.

Wang, C. (2005). Ownership and operating performance of Chinese IPOs. Journal of Banking \& Finance, 29(7), 18351856.

Xiao, Y., \& Yung, C. (2015). Extrapolation errors in IPOs. Financial Management, 44(4), 713-751. 